the discovery of large deposits of iron-ore beneath the driftcovered valley, a discovery made while digging or drilling the farm wells in this otherwise well settled agricultural district. The iron-bearing rocks, termed the Freedom formation, from the town of North Freedom, comprise slate, chert, dolomite, and iron-ore, and all gradational phases between these kinds of rock, including banded ferruginous chert like that in the iron-bearing series of Lake Superior. The author points out that the Baraboo preCambrian series may be compared with the upper portion of the Lower Marquette series, the Freedom formation corresponding with the Negaunee iron-bearing formation. Detailed accounts are given of the various rocks and drift deposits, and of the circulation of underground water.

The recent numbers of the Boletin del Cuerpo de Ingenieros de Minas del Peru, issued during 1904, continue to testify to the energy and activity of the Government officers charged with the development of Peru. No. 8 , by Señor Venturo, describes important deposits of hæmatite in the extreme north of the country, the ore appearing on the surface, and being probably derived from the dehydration of an old lake-iron deposit. Fragments of rocks from the margins of the former lake are found surrounded by the iron oxide, and the iron itself seems to have been dissolved out from the acid igneous masses in the neighbourhood.

In view of the demand for nickel for plating, for alloying steel, and for coinage, Senor Eduardo de Habich was sent to report on the nickeliferous veins of the province of La Mar, which present practically a virgin field. His memoir (No, II) seems encouraging, the chief ores being ullmannite and nickeline (kupfernickel), occurring mostly in veins of quartz, which may also contain both gold and silver. No. I2 has probably the widest interest for geologists in general, giving as it does the results of a visit to central Peru by Dr. Gustav Steinmann, of Freiburg-imBreisgau, early in 1904. Señor Elmore is the author of Boletin No. 13, on the water-supply of the Rimac valley. It is shown that the permeable subsoil in the valley-floor, from Chosica downwards, becomes charged with a good potable water by infiltration from the River Rimac, and this is capable of furnishing a healthy supply wherever it may be desirable to tap it. The marked rise of this underground water in Callao is interestingly attributed to the obstacle furnished by the neighbouring island of San Lorenzo. The economic aspect of Señor Elmore's report is sure to be widely welcomed in a populous and practically rainless district.

The fourteenth volume of the Berichte der naturforschenden Gesellschaft su Freiburg-im-Breisgau (1904) contains several papers of geological interest. A. Freiherr von Bistram's studies on the dolomitic region of the Alps of Lugano were commented on when they first appeared in separate form (NATURE, vol. lxix. p. riz). Walther Schiller and W. Paulcke are both concerned with the structure of the Engadine, the former giving a detailed account of the region south-east of Schuls, of which the Piz Lischanna forms the centre, while the latter examines the structure of a wider area, from Landeck to the basin of the Po.

Palæontological papers seldom contain so much personal revelation as is to be found in Herr Georg Boehm's first section of his Beitrage zur Geologie von NiederländischIndien (Palaeontographica, supplement iv. Stuttgart, 1904). The splendid series of ammonites therein described, probably from a Tithonian horizon, were obtained for the most part from the collection of a postmaster of Sula Besi, and from one of "die Alfuren," the latter name being applied to any uncivilised natives. Some specimens were even extracted from concealment in the scanty clothing of the boatmen. The postmaster and his allies appear, consciously or unconsciously, to have lost touch with the true locality of their finds, and to have opened up a delusive route through the forest in Taliabu, whereby Herr Boehm was led to a spot where he found abundant belemnites and Nuculæ, but none of the highly prized ammonites. The "Alfuren-Sammlung " proves to be of unusual interest, and may perhaps grow in the course of time, if judicious sums are expended on the "uncivilised" population. The inclusion of fossils smuggled in from other places is now, however, a possibility against which it will be difficult to guard.

No. 1836 , voL. 7 I]
Part ii. of the seventh volume of the Transactions of the Geological Society of South Africa (Johannesburg, 1904) bears witness to the prevalence of research in Africa in all branches of geology. Dr. Hatch contributes two papers, one in conjunction with Prof. Corstorphine, who has been drawn off from the service of Cape Colony into a more adventurous field. Mr. J. P. Johnson shows that two types of stone implements are found in the Taaibosch Spruit, the older and rougher lying beneath 15 feet of alluvium, and the newer type upon the surface. Mr. F. W. Voit furnishes a paper of general interest on the geology of German SouthWest Africa, in which a large series of ancient metamorphic rocks is dealt with; these are accompanied by intrusions of granite. The author urges that some of what might be regarded as ordinary contact-phenomena are here carried out on a regional scale, and must be referred to the action of pressure rather than to the invasion of the granite. The metamorphic rocks are impregnated with important deposits of copper-ore, sometimes localised in quartz veins, and sometimes spread in cloud-like masses through the schists.

In the first part of the Jahrbuch der k.k. geologischen Reichsanstalt for 1904 (September 15), Franz Toula describes the results of his journey to the Dobrudscha in 1892 and discusses in particular the forms of Exogyra met with. Dr. Petrascheck, in examining the granitic mass near Brixen, in the Adige valley, reviews the nature of Sederholm's "Myrmekite," an intergrowth of triclinic felspar and quartz, and concludes that it is a primary product of the consolidation of the igneous magma. Dr. Ampferer's important examination of the terraces along the valley of the Inn (pp. 91-160) should be considered by all who seek to explain the topography of glaciated areas. The author finds that the terraces of gravel rest on an earlier series of terraces cut in the rock, which are at very different levels on opposite walls of the valley. He summarises his results in a series of fifty-six propositions, among them being the conclusion that the Inn valley, on the retreat of the ice, exhibited a succession of shallow basin-like excavations, which were filled in later by a continuous deposit of alluvium. These hollows, like the smaller details of the ice-erosion, were formed independently of the hardness of the rocks concerned, and Dr. Ampferer believes that the variation in the activity of a glacier as an abrading agent depends in reality on variations in the local pressure and velocity. With reduced pressure and greater velocity the same amount of erosion can be performed as with greater pressure and less velocity. The author opposes the view that rock-obstacles on the walls of a valley are inevitably worn away by the passage of glacier-ice; he urges, on the other hand, that such irregularities may be left standing out, while others are actually produced by the lack of uniformity in the forces of erosion, to which he specially directs attention.

The Verhandlungen der k.k. geologischen Reichsanstalt, Nos. 9-I2, for IgO4, continue to be rich in papers on Bohemia and Moravia, and students of petrology in the broad sense, as well as of Palæozoic and Mesozoic faunas, must endeavour to keep pace with the monthly observations furnished by Dr. Katzer, Jaroslav J. Jahn, Friedrich Trauth, and others. The Dalmatian islands also receive attention in Dr. Waagen's reports of his recent journeys.

\section{AGRICULTURAL EDUCATION AND RESEARCH.}

THE writings of Henry, Babcock, King, and others have made the University of Wisconsin familiar to English agricultural students, so that considerable interest attaches to the twentieth annual report of the experiment station, which contains a short history of the College of Agriculture, and summarises the results of twenty years' research. The college is one of the best known in the United States, and its record is typical of many similar institutions. A professor of agriculture was appointed in 1866 , there was the usual attempt to teach before the materials for a course of university grade existed, and there was the usual failure. Then, when the indignation and forcible action of "some thirty representative farmers" led the regents of the uni- 
versity to realise the need of " better directed measures," there was a change of policy. The farmer's educational requirements were studied, suitablc courses were devised, and research in his interests was begun. The success of this changed policy is testified to by every chapter of the report, and is strikingly shown by the material progress of the institution. When the present director took charge in r 880 the buildings consisted of a dwelling house and two barns, worth about roool.; the present buildings are worth more than $60,000 l$. In 1881 the income of the agricultural department was represented by the salary of the professor and a grant of about $1000 \mathrm{l}$. for experiments. In 1903 the College of Agriculture had an income of 10,0ool. for administrative and teaching purposes, and of $6000 l$. for research; and in addition free instruction in languages, mathematics, and pure science was provided for agricultural students in other departments of the university.

But the "better directed measures" of the regents of Wisconsin University have had an influence outside the College of Agriculture. At the jubilee of the university last summer, Prof. Chamberlin, of Chicagro, delivered an address on " The State University and Research." In this address it was argued that " the fundamental promotion of education lies in an increase in the intellectual possessions of a people, and in the mental activities and attitudes that grow out of the getting, the testing, and the using of these possessions " (Experiment Station Record xvi., 3). As an illustration of the effects of properly directed research on a community, the work of the Wisconsin Experiment Station was referred to in the following words:"It was my privilege to compare the Agricultural conventions of this State at two periods separated by a decade, within which the experiment station became a potent influence. The dominant intellectual and moral attitude of the earlier period was distinctly disputatious and dogmatic. ... In the second period the dominant attitude was that of a scientific conference. . . The whole was characterised by a notable approach to the methods of approved scientific procedure. The intellectual and moral contrast of the two periods was one of the most pronounced expressions of advance in the higher education in a great mass of people in the midst of a practical life which it has ever been my privilege to witness."

The educational value of research may be traced here and there in our English shires, where agricultural experts have won the confidence of farmers by conducting well devised experiments in their midst. But our education authorities still view research with suspicion, and one finds agricultural experiments, for example, labelled "demonstrations" for no other reason than to satisfy the county auditor! One wishes that our education committees, entrusted as they are with funds for the encouragement of agriculture, would study the "better directed measures" which have been so successful in Wisconsin, and not in Wisconsin only, but throughout the States. They would probably find in the American institutions confirmation of a view expressed by Prof. Chamberlin in the above quoted paper.

He remarks that while it is a good thing to provide technical instruction in agriculture, it is " a much higher and truer function to develop the science of agriculture, to increase the intellectual activity of every farmer, to improve the agricultural art on every farm, and by such improved art to furnish better and safer food to every citizen.'

T. H. Middleton.

\section{SCIENTIFIC REPORTS OF THE LOCAL GOVERNMENT BOARD. ${ }^{1}$}

$A \mathrm{~S}$ is customary, the report under notice is divided into three portions, (I) an excellent digest by the principal medical officer, $\mathrm{Mr}$. Power, of the contents of the volume; (2) statistics of vaccination and details on outbreaks of disease investigated by the board's inspectors; and (3) the reports of scientific investigations carried out for the board, and of the board's vaccination department.

It is reassuring to learn that abstention from vaccination seems to be steadily diminishing, the percentage of

1 Supplement containing the Rep rrt of the Medical Officer for 1902 -3 (Thirty-second Annual Report of the Local Government Board, 1902-03.) births remaining unvaccinated being 20.8 in 1899,199 in 1900 , and 17.3 in 1901. The epidemic of small-pox which raged in London in $1901-2$ again directs attention to the danger of small-pox hospitals in disseminating this disease in their vicinity. Practically all the London cases were removed to the hospital ships moored in the Thames at Long Reach, opposite to which is the village of Purfleet, containing a number of unvaccinated persons, and an excessive incidence of small-pox prevailed there attributable to aërial conveyance of infection from the ships. The populations of Purfleet garrison and of the training ship Cormwall close by were, however, thoroughly vaccinated and re-vaccinated, and not a single case of small-pox occurred in these communities, another instance of the protective power of vaccination. The report by Dr. Bulstrode on outbreaks of typhoid fever at Winchester and Southampton attributable to infected oysters has already been noticed in these columns (see Nature, vol. 1xviii. p. 303)

An outbreak of throat illness at Lincoln attributable to milk was the subject of investigation by Dr. Mair. Although bearing considerable resemblance to scarlatina the outbreak was conclusively proved not to be one of this disease. From a few of the cases a yeast was isolated from the throat by Drs. Klein and Gordon which proved pathogenic to mice, and reproduced on inoculation some of the features of the human disease.

Dr. Bulstrode's report on the excessive incidence of typhoid fever at Bridgend (Glamorgan) supplies an instructive instance of the superiority of properly conducted bacterioscopic examination over chemical analysis for detecting a slight degree of pollution of water supplies. Turning to the scientific investigations carried out for the board, it is difficult in a short space to give adequate notice of their contents and importance.

Dr. Klein records some observations on the bacteriological diagnosis of plague, and the manifestations of this disease in the rat. He regards the natural disease in this animal as one of slight virulence and feeble infectivity, and considers that it is spread from rat to rat mainly through their fighting propensities. Dr. Klein, in continuation of his study of agglutinins, also details experiments made to test the ability of two or more agglutinins to coexist in the blood of the same animal. Cultures of B. typhosus and $B$. enteritidis (Gärtner) injected simultaneously in an animal were found to produce agglutinins corresponding to each of these microbes. But if the cultures were injected not simultaneously, but in sequence, the agglutinin of the first microbe was to a large extent replaced by that of the second microbe injected.

Dr. Sidney Martin has continued his investigations of the toxic substances elaborated by diarrhœa-producing bacteria, dealing in the present instance with those of the Proteus vulgaris. He finds the toxin to be proteid in nature, but not albumose, and readily extractable from the bacterial cells by distilled water. An injection of the toxin produced diarrhoea with depression of temperature.

The report by Dr. Mervyn Gordon on a bacterial test for the estimation of pollution of air is one of great interest and importance. First examining the natural bacterial flora of the saliva, he found that a streptococcus having the power of producing acid in glucose and in lactose media, acid and clot in milk, and of changing the colour of an anilin dye neutral red, was extremely abundant, no less than $10,000,000$, and in some cases $100,000,000$, being contained in 1 c.c. of saliva, and by using a neutral red broth and incubating anaërobically minute traces of saliva may be detected. By placing, therefore, dishes of neutral red broth at varying distances from a speaker, and subsequently incubating and examining, the distance to which particles of saliva may be carried can be ascertained. It was found that particles of saliva were present in the air no less than 40 feet in front of and 12 feet behind the speaker during loud speaking. Dr. Houston has carried out an exhaustive study of the bacterial flora of human dejecta, with special reference to the colon bacillus. He finds that not less than 90 per cent. of the total number of this organism present have the characters of the typical $B$. coli.

The same observer details the results of the chemicat and bacteriological examination of Tunbridge Wells deep well waters, and, in conjunction with Dr. Klein, reports on the use of nutrose agar for the identification of the typhoid bacillus. 